\title{
Implementation of road charging in the city of Žilina - a tool for reducing negative externalities
}

\author{
Alica Kalašová ${ }^{1,}$, Veronika Harantová ${ }^{1}$, Simona Kubíková $^{1}$, and Jerzy Mikulski ${ }^{2}$ \\ ${ }^{1}$ Department of road and urban transport, Faculty of operation and economics of transport and communications, University of Žilina, \\ Univerzitná 1, 010 26, Slovakia \\ ${ }^{2}$ University of Economics, 50, 1-Maja str, 40-287, Katowice, Poland
}

\begin{abstract}
It has been proven on several implementations worldwide, that introducing of road charging scheme in urban area is very simple and efficient way to reduce traffic volumes, lower congestions and shorten travel time. Herewith, there is a possibility of utilization of charged money, e.g. for financing of public transportation. In our paper, based on analysis of traffic intensities and results of social survey, we describe a proposal of charging schema for the central part of the city of Žilina in Slovakia.
\end{abstract}

\section{Introduction}

Toll collection is one of the ways that users of road network can pay for its utilization. Type of the vehicle, the distance run off in charging zone or the time period spent there are usually main factors to determine the rate of charging. There are three main reasons, why toll collection is introduced to:

- obtain finance that can be further used for construction of new road infrastructure or improvement of public transportation,

- to reduce emissions, noise and other negative externalities produced by transportation,

- to reduce congestions on selected roads (areas) or time periods in order to increase capacity of road network.

Nowadays, there is tend to build up and operate systems of electronic toll collection.
In table 1, there you can see examples of toll rate dividing into two parts - toll rate outside rush hour and in the rush hour. The toll rates are set per day or per entry to city centre. In the last column of table 1 , there is traffic reduction which is a result of toll collection implementation. A reduction of traffic volume in the city centres has an important positive effect on citizens, environment, as well as on better quality of life in cities.

Table 1 shows some examples of electronic toll systems in the chosen European cities [2]. These systems are based on DSRC and ANPR technologies.

Dedicated Short Range Communications (DSRC) is an open-source protocol for wireless communication, similar in some respects to WiFi. While WiFi is used mainly for wireless Local Area Networks, DSRC is intended for highly secure, high-speed wireless communication between vehicles and the infrastructure.

Table 1. Toll collection systems in European cities [10]

\begin{tabular}{|c|c|c|c|c|c|}
\hline \multirow{2}{*}{ City } & \multirow{2}{*}{ Start } & \multirow{2}{*}{ Technology } & \multicolumn{2}{|c|}{ Toll rate } & \multirow{2}{*}{ Traffic reduction } \\
\hline & & & outside rush hour & in the rush hour & \\
\hline Stockholm & 2006 & DSRC/ANPR & $\begin{array}{l}\text { 11-15 SEK/entry } \\
\text { (1-1,4€/entry) }\end{array}$ & $\begin{array}{l}\text { 25-35 SEK/entry } \\
(2,4-3,3 € / \text { entry })\end{array}$ & $20 \%$ \\
\hline London & 2003 & ANPR & $\begin{array}{c}10-14 £ / \text { day } \\
(11,2-15,7 € / \text { entry })\end{array}$ & $\begin{array}{c}10-14 £ / \text { day } \\
(11,2-15,7 € / \text { entry })\end{array}$ & $30 \%$ \\
\hline Bergen & 1986 & DSRC & $\begin{array}{c}\text { 10-30 NOK/entry } \\
\text { (1-3,1 €/entry) }\end{array}$ & $\begin{array}{c}20-56 \text { NOK } € / \text { entry } \\
(2,1-5,8 € / \text { entry })\end{array}$ & $7 \%$ \\
\hline Oslo & 1990 & DSRC & $\begin{array}{l}\text { 4-25 NOK/entry } \\
(0,4-2,6 € \text { /entry })\end{array}$ & $\begin{array}{l}5-31 \mathrm{NOK} / \text { entry } \\
(0,5-3,2 € / \text { entry })\end{array}$ & $5 \%$ \\
\hline Trondheim & 1991 & DSRC & $\begin{array}{l}11-15 \mathrm{NOK} / \text { entry } \\
(1,15-1,55 € / \text { entry })\end{array}$ & $\begin{array}{c}14-30 \mathrm{NOK} / \text { entry } \\
(1,45-3,1 € / \text { entry })\end{array}$ & $10 \%$ \\
\hline
\end{tabular}

\footnotetext{
*orresponding author: simona.kubikova@,fpedas.uniza.sk
} 
Automatic number-plate recognition (ANPR) is a technology that uses optical character recognition on images to read vehicle registration plates to create vehicle location data. It can use existing closed-circuit television, road-rule enforcement cameras, or cameras specifically designed for the task. ANPR is used by police forces around the world for law enforcement purposes, including checking if a vehicle is registered or licensed. It is also used for electronic toll collection on pay-per-use roads and as a method of cataloguing the movements of traffic, for example by highways agencies. [10,11]

The key advantage, comparing to traditional systems with toll plazas, is that there is no need to stop vehicles when executing the process of charging. It means that such system is not a source of congestions and does not affect the fluency of traffic flow in a negative way. Recently, in many European countries electronic toll collection was introduced on highways and main roads.

However, the same principles can be utilized in urban areas as well.

\section{Traffic characteristics of the city of Žilina}

Žilina is the largest city situated on the Váh River, located $49^{\circ} 15^{\prime}$ of northern latitude and $18^{\circ} 45^{\prime}$ of eastern longitude. With population of 82924 inhabitants (on 1st June 2019) and the area of 80,03 square kilometres it creates an important centre of northwest Slovakia.

As in other European cities, the traffic situation in Žilina is continually getting worse. Fast grow of individual transportation, descent of public transport together with development of new business and commercial activities in the city (manufacturers KIA MOTORS, MOBIS, and others) - all these processes make an important impact on the city communication system. There are about 68792 registered cars (on 31th May 2019) in the Žilina county, the level of automobilization is about 1 car per 2,5 inhabitants [5].

The most important part of the city communication system is a 4-lane city ring, which surrounds the central part of the city and ensures that no transit traffic will pass through it (Figure 1.).

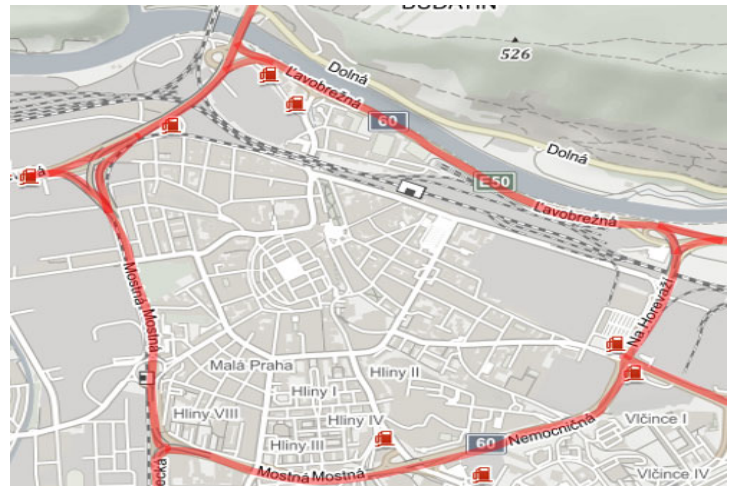

Fig. 1. Four - lane city ring of Žilina [5]

Although there can be found some bottlenecks on the city ring and in adjacent urban settlements, these problems are to be solved by better local organization of traffic or redesign of critical points. Also an intensive decrease of transit traffic is expected after completing of the highway next to the city.

The problem we deal with lies in the central part of the city where congestions and problems with parking irritate more and more people. Every year, Faculty of Operation and Economics of Transportation and Communications realizes a survey of traffic intensities on selected crossroads in Žilina. Results of these surveys, together with data gathered from several bachelor and diploma theses related to organization of traffic in the city, give us an opportunity to have a relatively detailed overview of traffic situation in Žilina within last 10 years. Based on the gathered data, we can see an unanimous increase of traffic intensities in covered area. The growth between years 2008 and 2018 reached up to $19 \%$ on one of the monitored crossroads.

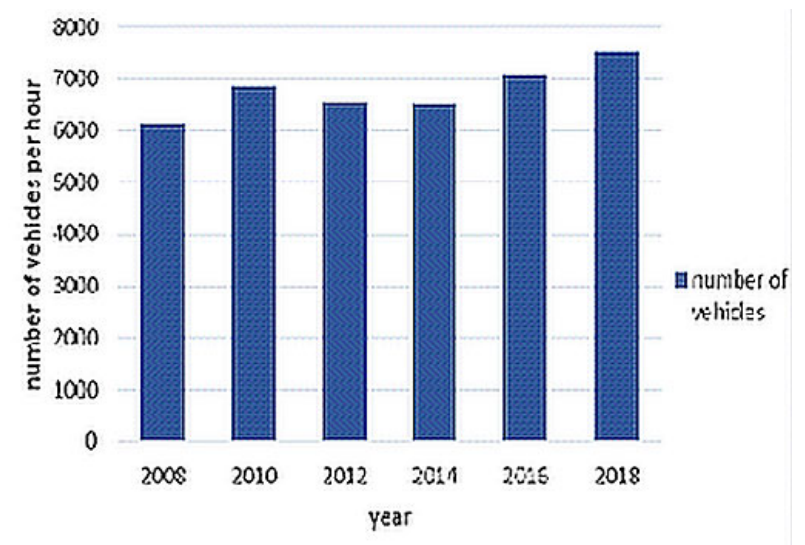

Fig. 2. Development of traffic intensities in covered area [6]

The growing traffic brings another related problem. As you can see in figure 3, the number of traffic accidents in Žilina County, is rising up [1].

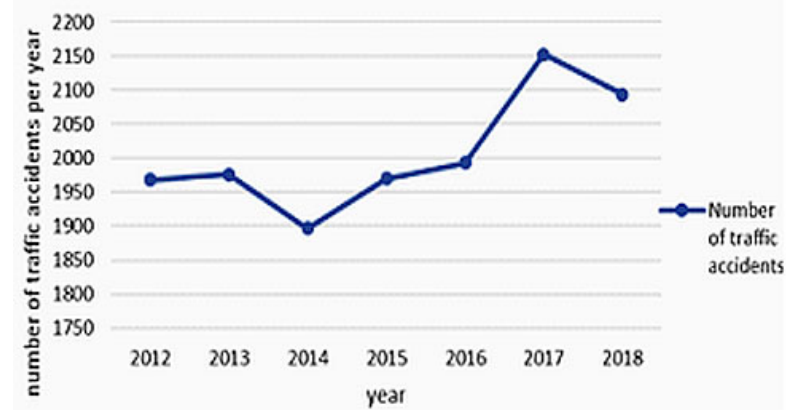

Fig. 3. The number of traffic accidents in Žilina [7]

On the other side, the utilization of public transport has dropped rapidly. As the statistics provided by Transport Company of the City of Žilina shows, there is a $21 \%$ dropdown but since 2015, $12 \%$ growth in passengers transported has been recorded. [4]. There are several reasons of this problem, inter alia insufficient financing of public transport and thus reduction of lines, disastrous organization of trolleybus network and at last but not least congestions that affect public transportation and make it unreliable $[9,12]$. 
Table 2 Utilization of public transport [4]

\begin{tabular}{|c|c|}
\hline Year & Number of passengers \\
\hline 2008 & 13505000 \\
\hline 2009 & 11838671 \\
\hline 2010 & 11312297 \\
\hline 2011 & 11120339 \\
\hline 2012 & 10890930 \\
\hline 2013 & 10630000 \\
\hline 2014 & 10809000 \\
\hline 2015 & 11015000 \\
\hline 2016 & 11411000 \\
\hline 2017 & 11650000 \\
\hline 2018 & 12053000 \\
\hline
\end{tabular}

Let have a look on parking situation in Žilina [3]. In 2002, Žilina-parking company was founded. $75 \%$ of the company share has a private investor and $25 \%$ belongs to the city of Žilina. New parking concept was introduced since 2003 which includes parking places for residents and visitors. There are three parking zones for visitors in the central part of the city with following prices:

- Zone A, historical city centre and area surrounding area for pedestrians $-1,5 € /$ first hour, each additional hour $2 €$, - Zone $\mathrm{B}$, around the historical centre $-0,8 € /$ first hour, each additional hour $1,6 €$,

- Zone $\mathrm{C}$, areas next to the city centre $-0,5 € /$ first hour, each additional hour $1 €$.

Besides, above mentioned parking places, there are several parking places operated by other private companies, where the price can differ. After the first year of operation, when the number of cars in central city zone dropped partially, the drivers get used on the parking fee and the system is no more successful as a regulation of traffic, it was just an example of short term regulation. Even the year-by-year increase of parking vehicles is $35 \%$ and the average fee paid by one car parking is approximately $0,6 €$. Because there are not enough parking places, the cars are often parking on pavement and this is very disturbing for pedestrians.

\section{The reasons and aims of implementing a toll collection system in Žilina}

As all the previous regulations, especially the parking system does not lead to reduction of traffic and congestions. We think that it is necessary to come with more sophisticated solution of the problem. There is no place for increasing capacity of the city communication system, contrariwise we have to eliminate amount of the traffic and toll collection is the way that we can achieve it. The concrete aims of toll collection are:

- regulation of vehicles entering central part of the city,

- better environment and conditions of living for residents,

- larger utilization of public transport,

- source of financing for public transport and road infrastructure.

It is necessary to take into account that toll systems bring together some risks and negative impacts as well.
For successful realization, it is necessary to focus on technological aspects and limitations, viability and financing of the system as well as public and political acceptance of the system. These factors will be discussed in the following paragraphs.

\subsection{An acceptance survey of a toll collection system in Žilina}

To know the level acceptance on toll system, an anonymous questionnaire survey in central city zone of Žilina was made in 2017. This survey included 15 questions prepared by Department of Road and Urban Transport, where it was also evaluated. In total, 383 questionnaires were collected.

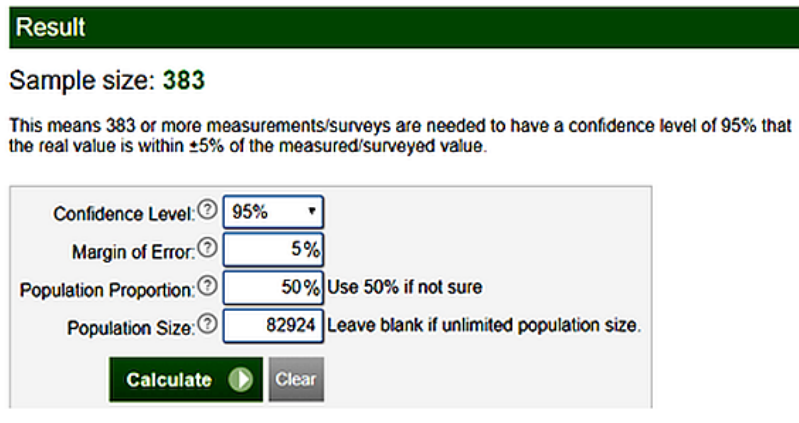

Fig. 4. The required number of respondents using Sample size calculator [8]

At first some basic facts about survey respondents: All the respondents were drivers parking in the central zone of the city - $62 \%$ men and $38 \%$ women. According to age structure, the largest part of them $(45 \%)$ was between 23 and 45 years old; $81 \%$ of respondents use private cars.

The survey gave us also the answer on how often the respondents visit the central zone. It is very interesting, that about $18 \%$ of respondents enter the central zone more than 4 times a day and $21 \%$ enter 3 times a day. Together with other respondents entering once $(41 \%)$ or twice $(20 \%)$ a day, we can see that $65 \%$ of questioned drivers were regular visitors.

It is also very important to know reasons of respondents' visits in the central zone. The survey showed, that about $40 \%$ of trips are related with work and business. Nearly the same part of visits is related with shopping (24\%) and private matters $(25 \%)$, the rest remains for free time activities (11\%). An alarming fact is that $65 \%$ of respondents do not use public transport for travelling to the central zone. Even other question showed that $44 \%$ of questioned people use the public transport less than once a day in average.

Other parts of questionnaires were related to satisfaction with traffic situation and the awareness of toll payment. Nearly $65 \%$ consider the situation to be critical and see the increase of cars, $31 \%$ are relatively satisfied, and only $4 \%$ think that there is no problem. However, that the majority of respondents (87\%) agree with the idea that there should be some regulation processes before the traffic system becomes uncontrollable. 


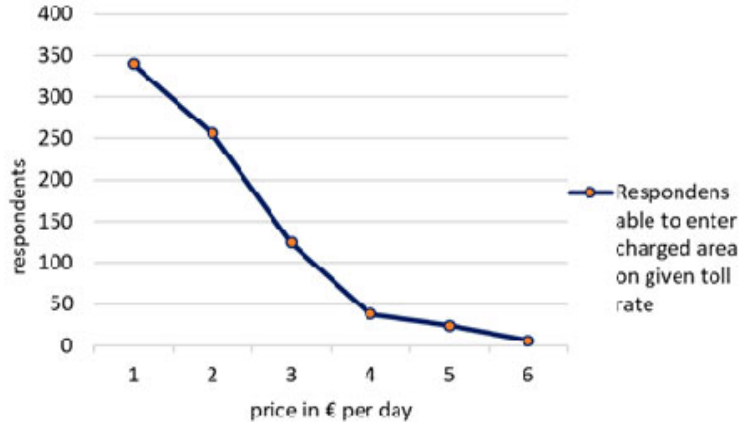

Fig. 5. Respondents able to enter charged area on given toll rate [own study]

Regarding to the awareness of the fee for entering central zone of the city, figure 5 shows how many respondents would be still able to enter the zone by car on given fee levels. The results of question „What is the fee level, which would certainly influence your decision what kind of transport mean to use to travel to the central zone?" are showed in figure 6 .

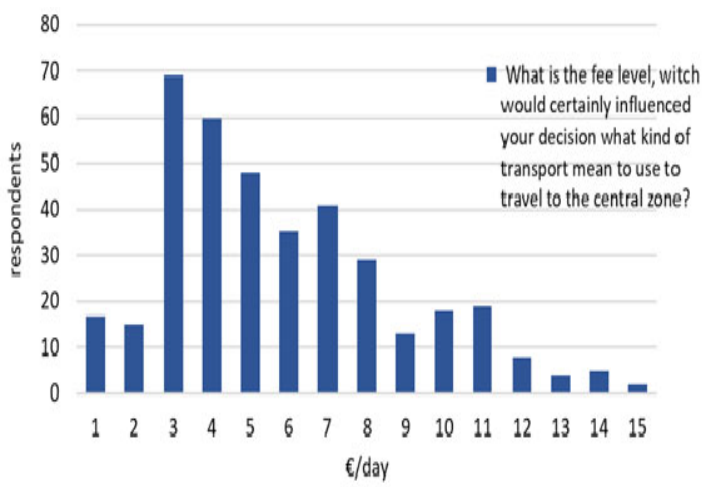

Fig. 6. The impact of given toll rate on respondents [own study]

\subsection{The chosen area covered by charging}

As was mentioned before, the main traffic related problems in Žilina are congestions and parking organisation in the central part of the city. We have prepared two possible variants, in both of them cordon method of charging where the payment is done on the entrance to the zone seems to be the best solution.

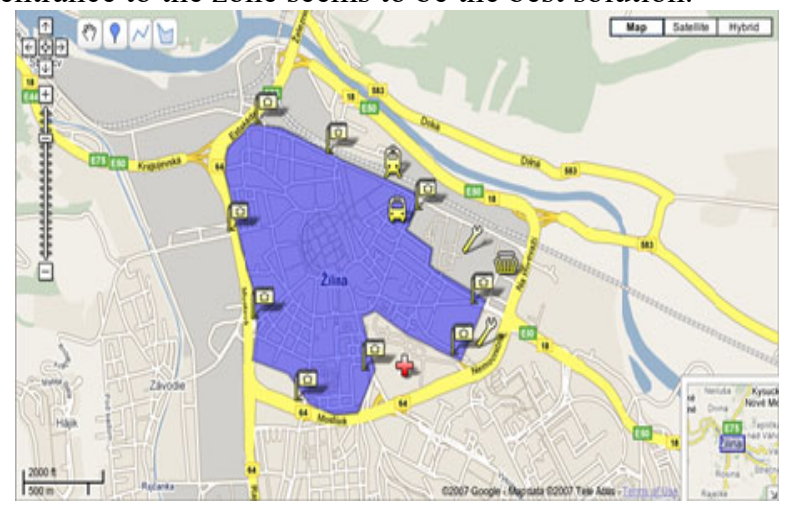

Fig. 7. The chosen area for charging with entrance gates [own study]
First, smaller variant assumed that only the interior part of city central part is affected by road charging. In that case, installation of 12 entrance gates would be necessary. However, with knowledge of traffic relations in solved area we suppose that this variant would not solve the problem. Probably it would make even increase problems with parking in surrounding areas and in this case, increase in utilization of public transport cannot be expected.

The second variant assumes to cover entire central part of the city with some exceptions (hospital, industrial park and shopping centre in the east). On the boundary of this area are opportunities to build parking places and provide the interchange to public transport. Another advantage is that in this configuration, only 9 entrance gates are needed (see figure 7).

\section{A proposal of a toll collection system in Žilina}

Other important step is to set the operation time of the system. That would have impact on the volume of traffic within traffic peaks and can help to decrease its oscillation during the day. Here we can utilize the knowledge earned in other cities where toll systems are in operation. The most common time of the operation is from 7.00 to 18.30 on working days.

\subsection{Proposed technology for toll collection}

When looking for the suitable technology, we are considering two factors:

- cost of the system - infrastructure and operation costs, - cost of the equipment in vehicle

As can be seen in table 1 , there are three main technologies for electronic toll collection. We assume that utilization of GPS system is not suitable for area of this size. Technology of DSRC is suitable, but it requires each car to be equipped with OBU. However, the system based on number plate recognition (ANPR) does not require any additional car equipment. When we consider that in all cases, there should be some kind of enforcement, this technology seems to be ideal for our solution and its reliability was proven in London. [3]

\subsection{Toll rates}

Setting the rate for entering solved area is the key step for successful realization of the project. When the price will be too high, there will be a negative impact on the traffic in the area. On the other side, when the fee will be too low, the toll collection will not solve anything, because it will not fulfil the aims, for which it was introduced. It is necessary to say that the fee would be probably paid once a day, no matter how often the car will enter the area. We also suppose that after introduction of toll there will be no other fees for parking in solved area. When determining the fee rate we took into account:

- average loan (it is $20595 €$ in county of Žilina),

- current fees for parking (1-2€),

- results of the acceptance survey. 
Based on the mentioned criteria, we can consider 3 - $4 €$ to be an ideal fee rate. This rate is higher than the price for parking, so it is expected, that it will have the regulation effect, on the other side, it is relatively acceptable comparing to average loan. This level seems to be a good compromise according to results of acceptance survey.

\subsection{Discounts, exceptions of payment}

When thinking about who should have exception from payment, we have to go out from the aims of the toll system. As we remind that one of the aims is to reach higher utilization of public transport, it is clear that public transport vehicles should be free of charge. There can probably be some kind of discount for taxi vehicles. As we want to provide better environment conditions for residents, their vehicles should have some kind of discount as well. Of course there should be no fee for ecological vehicles (electrical, hybrid) and vehicles of police and rescue services.

\subsection{Methods of payment}

Together with realization of road charging, the system of payment must be designed. Several applications have showed that payment with utilization of internet and mobile phones is easy and simple. Of course, more alternatives how to pay help to better acceptance of the systems, so there should be other possibilities how to pay, for example on petrol stations, post offices or other selected places, a registered card payment can also be used.

\section{Conclusion}

There are many other important steps, which have to be taken prior to successful realization of road charging system. It must be clear, who will be the owner and operator of the system and who can provide the money for its installation. Not less important is the question how the profit from the operation will be used. According to our opinion, the profit should be used for improvement of the traffic situation in charged area, because its users will be affected by the system. However, it does not mean that we will build new roads and parking places at the expense of disruption green areas - we can rather focus on improvement of public transport. In Slovakia, there is not yet convenient situation for introduction of toll systems in cities. However, the capital Bratislava introduces lowemission zones in the city centre. Together with some legislative steps, it is necessary to inform the public about possibilities we have. By informing the public, we can reach our target - to increase the level of acceptance on road charging systems in cities and to show the benefits these systems can bring.

\section{References}

1. V. Konečný, Analýza dopadov dopravy na životné prostredie (Analysis of transport impacts on environment), In proceedings of From Horse-drawn Railway to High-speed Transportation System, ČVUT Praha (2007), ISBN 978-80-01-03699-0.

2. P. Urbánková, Úvod do mýtneho systému, Projekt Zavádění mýta ve městech $\mathrm{v}$ podmínkách ČR, available on : http://www.telematix.cz/projekty

3. Parking company Žilina, http://www.parkovaniezilina.sk

4. Transport Enterprise of the city of Žilina, http://www.dpmz.skz

5. Basic information about the city of Žilina and Žilina region, http://www.zilina.sk/

6. Traffic accidents in the Slovak republic https:/www.ssc.sk/files/documents/dopravneinzinierstvo

7. Slovak statistics in transport, https://www.minv.sk/?kompletna-statistika

8. Sample size calculator online, https://www.calculator.net/sample-size calculator.html? type $=1 \& \mathrm{cl}=95 \& \mathrm{ci}=5 \& \mathrm{pp}=50 \& \mathrm{ps}=82$ $924 \& x=72 \& y=35$

9. R. Berežný, V. Konečný: The impact of the quality of transport services on passenger demand in the suburban bus transport, Procedia Engineering, Vol. 192, p. 40-45 (2017)

10. A. Kalašová, S. Kubíková, J. Kupčuljaková: Traffic Time Delay Modelling on the Intersection in the City of Martin, Using Software Aimsun, Recent advances in traffic engineering for transport networks and systems Book Series: Lecture Notes in Networks and Systems Volume: 21 Pages: 203-212 (2018)

11. A. Kalašová, K. Čulík, S. Kubíková: Smart City Model of Sustainable Development of Cities, Conference: 11th International Scientific and Technical Conference on Automotive Safety proceedings paper (2018)

12. A. Kalašová, J. Kupčuljaková: The future in the telematics applications as support for increased safety, Transport problems, Vol. 7, pages 103-109 (2012)

This contribution is made within project VEGA 1/0436/18 Externalities in road transport, an origin, causes and economic impacts of transport measures.

This contribution is the result of the project implementation: Centre of excellence for systems and services of intelligent transport II.,

ITMS 26220120050 supported by the Research \& Development Operational Programme funded by the ERDF.
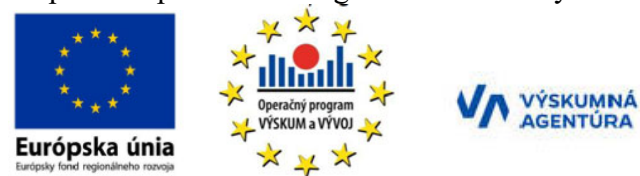

"Podporujeme výskumné aktivity na Slovensku/Projekt je spolufinancovaný zo zdrojov EÚ" 